\title{
Revising the WHO Essential Medicines List for paediatric rheumatology
}

\author{
Christiaan Scott ${ }^{1}$, Nicola Smith ${ }^{2}$, Rebecca James ${ }^{3}$, Ben Whitehead ${ }^{3}$, Rochelle Green ${ }^{4}$, Helen E. Foster ${ }^{5^{*}}$ (D) on behalf \\ of the Paediatric Global MSK Task Force
}

\section{Dear Editor,}

The World Health Organisation (WHO) Essential Medicines List (EML) [1] informs countries about the minimum medicine items necessary to meet priority health needs of the population and guide national and institutional medicine lists, especially in Low Resource Income Countries. The current EML under medicines for 'joint diseases in children' does not reflect current best practice [2] and an important theme of work from the Paediatric Global Musculoskeletal Health Task Force (TF) [3] is to revise the listing for medicines relevant to paediatric rheumatic diseases.

Healthcare professionals working in paediatric rheumatology and who are TF members were invited to take part in an anonymous online survey WHO EML to explore which drugs they deemed to be 'essential' and 'ideal' for the clinical practice in their context. No reminders to the survey were sent. We had 97 responders, from 43 countries across all continents and mainly from low resource countries (Asia $n=51$ / 97). Respondents had a range of $1-35$ years of clinical practice and included consultant grade paediatric rheumatologists $(n=77)$, consultant general paediatricians with interest in rheumatology $(n=13)$, paediatric rheumatology trainees $(n=3)$, adult rheumatologists $(n=3)$ and a nurse working in paediatric rheumatology $(n=1)$. Survey data were analysed by applying descriptive statistics and free-text comments were analysed following standard procedures for qualitative analysis [4].

Most respondents $(n=70 / 97,72 \%)$ reported that a revised EML would very likely improve access to medicines in their country, improve drug accessibility within their clinical practice, provide assistance when negotiating with healthcare agencies or insurance companies and further increase awareness about paediatric rheumatology issues. They deemed that the EML should list the drugs in Table 1; 80\% respondents identified 5 agents as 'essential' (oral, intra-articular and intravenous corticosteroids, NSAIDS, Hydroxychloroquine and Methotrexate [oral and subcutaneous]) and a wide range of synthetic and biologic DMARDS as well as other immunosuppressive agents be included. This 'cut off' of $80 \%$ will form the basis of the TF application to the WHO to revise the EML with the submission planned for late 2020. It is our hope that raising awareness and improving access to appropriate therapy will lead to better outcomes for children with rheumatic diseases globally and allow for a targeted treatment approach [5].

\footnotetext{
* Correspondence: h.e.foster@newcastle.ac.uk

${ }^{5}$ Population and Health Sciences Institute, Newcastle University, Newcastle upon Tyne, UK

Full list of author information is available at the end of the article
} 
Table 1 Suggested medicines to be included in the WHO EML

\begin{tabular}{|c|c|c|}
\hline Drug & $\begin{array}{l}\text { Should Include } \\
\text { (Ideal) (\% refers } \\
\text { to respondents) }\end{array}$ & $\begin{array}{l}\text { Inclusion } \\
\text { 'Essential' }\end{array}$ \\
\hline Oral prednisolone & $100 \%$ & $92 \%$ \\
\hline Oral NSAIDs & $99 \%$ & $93 \%$ \\
\hline Hydroxychloroquine & $98 \%$ & $88 \%$ \\
\hline Intravenous Methylprednisolone & $98 \%$ & $83 \%$ \\
\hline Methotrexate oral & $96 \%$ & $81 \%$ \\
\hline Mycophenolate Mofetil & $95 \%$ & $77 \%$ \\
\hline Azathioprine & $94 \%$ & $71 \%$ \\
\hline Methotrexate subcutaneous & $91 \%$ & $80 \%$ \\
\hline Intravenous cyclophosphamide & $91 \%$ & $77 \%$ \\
\hline Adalimumab & $91 \%$ & $71 \%$ \\
\hline Anakinra & $90 \%$ & $60 \%$ \\
\hline Etanercept & $87 \%$ & $70 \%$ \\
\hline $\begin{array}{l}\text { Intra-articular corticosteroid } \\
\text { Triamcinolone Hexacetonide }\end{array}$ & $86 \%$ & $64 \%$ \\
\hline Intravenous Tocilizumab & $86 \%$ & $63 \%$ \\
\hline Oral prednisolone (soluble) & $86 \%$ & $55 \%$ \\
\hline Ciclosporin & $85 \%$ & $52 \%$ \\
\hline Sulphasalazine & $84 \%$ & $51 \%$ \\
\hline Subcutaneous Tocilizumab & $81 \%$ & $46 \%$ \\
\hline Infliximab & $80 \%$ & $52 \%$ \\
\hline $\begin{array}{l}\text { Intravenous bisphosphonate } \\
\text { (e.g. pamidronate) }\end{array}$ & $76 \%$ & $37 \%$ \\
\hline $\begin{array}{l}\text { Intra-articular corticosteroid } \\
\text { Triamcinolone Acetonide }\end{array}$ & $72 \%$ & $28 \%$ \\
\hline $\begin{array}{l}\text { Intra-articular corticosteroid } \\
\text { Methylprednisolone }\end{array}$ & $45 \%$ & $25 \%$ \\
\hline Oral cyclophosphamide & $41 \%$ & $16 \%$ \\
\hline Inhaled analgesia (nitrous oxide) & $36 \%$ & $15 \%$ \\
\hline Thalidomide & $34 \%$ & $8 \%$ \\
\hline \multicolumn{3}{|l|}{ Total Respondents: 97} \\
\hline
\end{tabular}

\section{Abbreviations}

EML: Essential Medicines List; TF: Paediatric Global Musculoskeletal Task Force; WHO: World Health Organisation

\section{Acknowledgements}

We are grateful to all the Paediatric Global Musculoskeletal Task Force members who participated in the survey.

\section{Authors' contributions}

The concept and case of need for the survey was led by HF and CS. All authors contributed to the survey content. NS set up the online survey and analysed the data. All authors read and approved the final manuscript.

\section{Funding}

Not applicable, this work was not funded.

\section{Availability of data and materials}

All data generated or analysed during this study are included in this published article (and it's supplementary information files).

\section{Ethics approval and consent to participate}

Formal ethical approval was not required. Survey respondents consented to participation through submitting a completed online survey response.

\section{Consent for publication}

Not applicable.

\section{Competing interests}

The authors declare they have no competing interests.

\section{Author details}

${ }^{1}$ Paediatric Rheumatology, University of Cape Town, Cape Town, South Africa. ${ }^{2}$ Translational and Clinical Research Institute, Newcastle University, Newcastle upon Tyne, UK. ${ }^{3}$ Paediatric Rheumatology, Queensland Children's Hospital, Brisbane, Queensland, Australia. ${ }^{4}$ Pharmacy, Queensland Children's Hospital, Brisbane, Queensland, Australia. ${ }^{5}$ Population and Health Sciences Institute, Newcastle University, Newcastle upon Tyne, UK.

Received: 6 September 2020 Accepted: 11 January 2021

Published online: 23 January 2021

\section{References}

1. The WHO Essential Medicines List 2019 [Available from: https://www.who. int/medicines/publications/essentialmedicines/en/.

2. Foster HE, Scott C. Update the WHO EML to improve global paediatric rheumatology. Nat Rev Rheumatol. 2020;16:123.

3. Foster HE, Scott C, Tiderius CJ, Dobbs MB. The paediatric global musculoskeletal task force-'towards better MSK health for all'. Pediatr Rheumatol. 2020;18(1):1-3.

4. Rapley T. Some pragmatics of data analysis. In: Silverman D, editor. Qualitative research:issues of theory, method and practice, vol. 3. London: Sage; 2011. p. 273-90.

5. Ravelli A, Consolaro A, Horneff G, Laxer RM, Lovell DJ, Wulffraat NM, et al. Treating juvenile idiopathic arthritis to target: recommendations of an international task force. Ann Rheum Dis. 2018;77(6):819-28.

\section{Publisher's Note}

Springer Nature remains neutral with regard to jurisdictional claims in published maps and institutional affiliations.

\section{Ready to submit your research? Choose BMC and benefit from:}

- fast, convenient online submission

- thorough peer review by experienced researchers in your field

- rapid publication on acceptance

- support for research data, including large and complex data types

- gold Open Access which fosters wider collaboration and increased citations

- maximum visibility for your research: over $100 \mathrm{M}$ website views per year

At BMC, research is always in progress.

Learn more biomedcentral.com/submission 